\title{
A Gloomy Carnival of Freedom
}

\section{Sex, Gender, and Emotions among Polish Displaced Persons in the Aftermath of World War II}

\author{
Katarzyna Nowak
}

\begin{abstract}
This article investigates the experiences of Polish Displaced Persons (DPs) through the lens of sexuality, analyzing their perceptions of liberation and life in DP camps in Allied-occupied Germany and Austria (1945-1951). It draws on a wide array of sources, including archival material, memoirs, and letters. Employing Mikhail Bakhtin's concepts of carnival and the carnivalesque, it argues that the dynamics of DPs' sexual and romantic encounters, analyzed as emotional experiences, can be characterized as having a carnivalesque structure of oppression, eruption, and normalization. It demonstrates how the eruption of sexuality (including sexual violence) was connected to the wider problems Poles faced, including feelings of emasculation, war trauma, and the challenges of rebuilding a community in exile. Polish elites, acting mostly within a Catholic conservative register, boosted normalization by combatting perceived "immorality" and promoting family values. To this end, they cooperated with international organizations and the Allied military in an attempt to contain venereal disease, prostitution, and abortion. Many of these efforts focused on policing women's bodies and regulating their sexuality, as a part of rebuilding the nation after the hecatomb of war.
\end{abstract}

KeYwords: carnivalesque, emotions, gender, Polish Displaced Persons, sexuality, WWII aftermath

Adam Tomaszewski, a Polish soldier imprisoned in Nazi Germany, remembered liberation and the first days of freedom as "bacchanalia," "revue of the absurd," and "chaos." Like many other liberated Poles, he invoked images of indulgence, sex, violence, and robberies fueled by alcohol. He struggled to find the right words to describe his emotions and the world in which he found himself after his liberation from the Westerminke POW camp in May 1945. ${ }^{1}$ A crowd of liberated people went out into the squares and streets across western Germany and Austria to celebrate the freedom granted them by Allied soldiers. Liberation, however, did not bring the peace Dis- 
placed Persons (DPs) had imagined. The festival of freedom was quickly followed by the transition to DP life, seen as a liminal phase between wartime and "real life." Sexual and gender transgressions from the war, liberation, and early postwar periods were a manifestation of the wider problems Polish DPs faced: feelings of emasculation, war trauma, and the challenges of rebuilding a community in exile.

At the end of the war there were approximately 1.4 million citizens of prewar Poland in the three Western zones of Germany and Austria, including the Polish soldiers under British command. ${ }^{2}$ The Allied powers categorized most of them as DPs, defined as "civilians outside the national boundaries of their country of origin by reason of the war, who are desirous but unable to return home without assistance." ${ }^{3}$ Allied military authorities and the United Nations Relief and Rehabilitation Administration (UNRRA) took charge of housing and repatriating those classified as DPs. According to the official UNRRA statistics, there were $250 \mathrm{DP}$ camps at the end of 1945 and more than 700 in $1947 .{ }^{4}$

DP camps lumped together people of different ages, genders, social origins, and wartime records. The Polish DPs in the American, British, and French zones were mostly former forced laborers, inmates of prisons and concentration camps, evacuees from Poland, Wehrmacht soldiers of Polish origin, and prisoners of war. As historian Anna Holian has argued, DPs defined themselves and understood their displacement in relation to the persecution they suffered. ${ }^{5}$ Thus, Polish DPs soon emerged as a separate community with goals and rules stipulated by Polish refugee elites, who were largely under the influence of the Polish government-in-exile and the Polish armies in the West.

This article examines how Polish DPs experienced the process of liberation, and considers their lives in the immediate postwar period. It concentrates on the sexual experiences of Polish DPs, the forms and meanings of their intimate relationships, and the response of Polish community leaders. Sexuality, repressed during the war, exploded after liberation. Sex was a common occurrence in the DP camps during the initial stage of their existence. After a few months, priests, teachers, doctors, and other elites in the DP camps tried to regulate the residents' sexual lives in accordance with prewar moral standards. This dynamic reflects the wider emotional trajectory experienced by many DPs after the end of the war, including an initial sense of empowerment, followed by confusion and, finally, embitterment, as Poles realized that they would not be able to control their own postwar destiny.

The war, experienced as both emasculating and defeminizing, engendered frustration, rage, hate, loneliness, and fantasies of indulgence. After liberation, Poles in occupied Germany compulsively tried to deal with these emotions on an individual and collective level. Many sought revenge, compensation, joy, and empowerment. Polish exile elites looked on these excesses with alarm. They aimed to reassert the primacy of marriage to save Poles from further moral and physical "degeneration." Their attempt to reconstruct marital domesticity in the unhomely space of the refugee camps reflected a wider national aim-strengthening the nation by policing women's and men's bodies. The underlying belief that war disrupted gender roles and therefore encroached on the very basis of Polish society - the patriarchal family - was fueled by the fear of homosexuality, prostitution, and other acts elites defined as depravity. 
I employ Mikhail Bakhtin's idea of carnivalesque transgression to describe the atmosphere of the liberation and the process of acclimatizing to the new DP life. I use the example of invigorated sexuality and its further normalization in the institution of marriage, attempts at reforming unmarried mothers, and marginalization of socalled disruptive elements. Bakhtin's theory, coined within literary studies, describes the dynamics of the social institution of carnival and its influence on literary modes. Within the space of carnival, such as the medieval Feast of Fools, people experience what Bakhtin called "the world upside down" in which opposite categories are muddled and social hierarchies are reversed. For a brief moment, what was repressed may thrive, the ruled may rule, the sacred is humiliated, and the profane is elevated. All this happens in a grotesque atmosphere of joy, enhanced by the sense of bodily unity. However, the topsy-turvy world of the carnival is fleeting; any empowerment it seems to offer is merely an illusion. Inevitably, the existing system of power relations reasserts itself and normalcy is restored. In this article, I argue that Bakhtin's notion of the carnivalesque allows us to understand the emotional experiences of Polish Displaced Persons as they moved from the moment of liberation into the new realities of the postwar world. ${ }^{6}$

This article is structured according to Bakhtin's trajectory of carnivalesque transgression, with its phases of oppression, eruption, and normalization. First, I briefly address the prewar and wartime regulation of sexuality and explore the outburst of bodily experiences that accompanied liberation. Second, I use personal accounts from the time to show how DPs envisioned liberation and the immediate postwar moment, highlighting their fantasies of empowerment and transgression. Third, I look at the ways conservative elites shaped the process of normalization, which included mass marriages, abortions, and a campaign against venereal disease.

The article makes extensive use of a wide range of sources, including memoirs and testimonies, the DP press, and archival records. Personal documents are used here to probe authors' perceptions and worldviews. Thus, they are seen, as Annette Wieviorka puts it, not as "factual truth, but the more subtle and just as indispensable truth of an epoch and of an experience." ${ }^{7}$ Records preserved in the Polish Institute and Sikorski Museum (London) and Piłsudski Institute of America (New York) give insights into processes of creation and self-understanding of the Polish exile community, while medical reports from United Nations Archives (New York) show how UNRRA workers and Polish leaders regulated intimate life and matters of public health in the DP camps.

\section{"For the Time of Oppressing, a Time of Embracing": Oppressed Sexuality in Wartime}

Polish DPs believed that the experience of the total war reached deeply into human bodies and minds, influencing their sexuality and mores. DPs saw their attitudes toward intimate life as a result of the years of oppression. During wartime, displaced Poles were subjected to extreme forms of corporeal oppression, including hunger, imprisonment, torture, rape, forced prostitution, humiliation, sexual deprivation, and 
forced labor. In the postwar period, DPs struggled to come to terms with these experiences. For example, for Tadeusz Borowski, a former concentration camp prisoner and an inmate of a DP camp near Munich, the experience of wartime oppression was transformed into embitterment and anger. ${ }^{8}$ In his poems and letters, Borowski carefully examined his new position and concluded, "What democracy gave me is an SS uniform and a dwelling in SS barracks." ${ }^{\prime 9}$ The loss of love and sexual life explored in some of his poems turned into hate and a desire for revenge. He raged against what he perceived as the normal life of Germans, noting the "beautiful women," "men in white summer clothes," and "pink tots." ${ }^{10}$ The lyrical subject of his poems fantasized about gang rapes, smashing the heads of infants, and mass executions, showing the fine moral line between the oppressor and the victim. ${ }^{11}$ Borowski encapsulated his mood at the end of the war with these phrases:

We will steal gold and meat,

We don't want to starve anymore.

We will smash soldiers and gendarmes,

We will break sticks and bayonets,

For us-cinemas, theaters, cafes,

For us-food, cars, and women. ${ }^{12}$

Although most of the DPs did not express the desire for compensation so eloquently, many wanted to take part in the spoils of war. Robberies, rapes, and murders followed the liberation. ${ }^{13}$ Some of those who were not too weak or ill tried to take back what they believed was rightfully theirs and to do whatever they wanted to celebrate the end of years of humiliations. "Germans robbed us too," one of the DPs explained to a priest later. ${ }^{14}$ A Polish POW noted in his memoir, "Germans took our things in Poland so when we entered [Germany] we took theirs." ${ }^{15}$ Bronisław Szneliński, who volunteered for labor in Germany, recalled the first days after the liberation in similar terms: "Then came the day for Germans to pay. Our people went from house to house and destroyed, tore, cracked, smashed, chopped everything. There were eight days of absolute freedom. Everybody did what he wanted, one took revenge on the other, everyone tried to get even."16 Many Poles, motivated by desire for revenge and, even more, by desire for compensation, celebrated the liberation with indulgence and excess. The war was experienced as emasculating - for individuals and for the nation. The liberation brought compulsive attempts to deal with these emotions. People, especially men, engaged in an orgy of freedom and in fantasies of sex, power, and adventure.

\section{"Dissolute Interregnum": The Eruption of Sexuality and First Responses}

"Prisoners went wild with joy. They laughed, cried, hugged everyone no matter what was their nationality, religion, and race. Freedom, freedom roared the voices, ${ }^{\prime 17}$ wrote Czesław Grądzki, describing the liberation of the concentration camp where he had been imprisoned for years. Many Polish DPs described the end of the war using words such as hope, freedom, joy, cheer, momentousness, agitation, revival, May celebra- 
tion, spring, chaos, enthusiasm, explosion, breakthrough, and change. While many Poles referred to a quasi-carnivalesque atmosphere in their accounts of liberation, they struggled to express its nature. For many, liberation was more than simply a joyful experience. It was an explosion in which contradictory feelings were intermingled. This emotional maelstrom accompanied them for days, weeks, and even months after the liberation.

DPs engaged in a sort of "festival of freedom" that had at its core an eruption of sexuality and other corporeal experiences. People ate, drank, rested, and made love. In this moment, sexuality seemed freed from the usual constrictions and social norms. Many felt liberated not only from physical enslavement, but from the fetters of tradition. Others were critical of postwar sexual encounters. Some called them "orgies," while others described them as a "quest for love and warm human contact." In his poem "The End of the War," Tadeusz Borowski depicted the eruption of sexuality after liberation as follows:

A sodomitical evening

In the tents, in the waschraums ... .

In the barrack, on the grass, under the wall,

A Frenchman is screwing, a Hungarian is screwing

A Polish man is screwing with a Polish woman in the hole,

A soldier-Negro is screwing with a German woman,

A priest is screwing among the tarts,

Mister lawyer is screwing in the corner,

A Jew is screwing and, of course,

Mister artist is screwing alone,

He's a tenor-masturbator,

Both genders and all the nations,

"Liberation!" They are right. ${ }^{18}$

A similar vision of liberation as bacchanalia was presented by Adam Tomaszewski. He described his experiences in a book published in 1978 in Canada that was situated between an autobiographical novel and a semifictional memoir. In this book, Tomaszewski characterized the postwar outburst of freedom as "a complete bedlam. There is no power." ${ }^{19}$ Within this no-man's-land, "a great fun of the winners at the expense of the defeated" took place for days and weeks. ${ }^{20}$ An abundance of food, drink, and cigarettes pushed the liberated along with their liberators toward an "international brotherhood," depicted as a kind of great reunion, mingling languages and bodies. ${ }^{21}$

In the first days after the liberation, people drunk with freedom and vodka felt bewildered and dizzy. "During these first days we have had an impression that we have won the war," confessed Tomaszewski, referring to the suddenly empowered crowds that "went out to the streets, danced, sang, got frantic with joy." 22 A farmer from the village of Wola Kożuszkowa recounted that after three hundred women were sent to his camp in Bochum nobody cared about "loose morals." In his memoir, published in a 1967 volume on the wartime experiences of Polish peasants, he recalled it as "the pure heresies of our proletariat." 23 
In his autobiographical novel begun in the Haren/Maczków DP camp and published in 1957 in Paris, Tadeusz Nowakowski depicted the situation in a German town after liberation as a "dissolute interregnum." He described a wild crowd of liberated people ransacking, destroying, killing, raping, getting drunk, and overeating. In this gloomy quasi-carnivalesque environment, people did everything that had been forbidden during the war, things they had only dreamed about. He called the first night after the liberation "an unconscious night." ${ }^{24}$ As he remembered it:

After night fell, the groans of the poisoned grew louder, and by midnight a mob of ex-prisoners broke in among the sleeping Polish and Ukrainian women. There were scuffles, short cries, curses, laughter, crying, whimpering. Then they lay down and breathed together, tangled in knots, reconciled, covered with stolen blankets and rugs, under the canopy of hanging sheepskins. "A ja ne mohu, ne mohu" [But I can't, I can't], one of the men lamented.

Outside the camp, vehicles raced continually back and forth along the highway, guns rumbled in the distance, and a muffled humming came from the sky. In the hall, through a cloud of cigarette smoke and stifling human odors, you could hear the sick groaning and begging for water, drunken peasants snoring, mothers singing lullabies softly in dark corners, loud smacking kisses and giggles under blankets, hoarse declarations of passion, men grunting and panting. Now and then a girl would burst into hysterical laughter or tears. There were continual quarrels when partners were exchanged. The diarrhea sufferers made the air fouler and fouler ... In the dim light of dawn the hall looked like a battlefield. Hundreds of sweating, fetid, sticky bodies were thrown together in one enormous heap. ${ }^{25}$

As this passage makes clear, in this carnivalesque chaos the boundaries between consensual sex and rape were often unclear. In most cases, the violence was primarily directed at Germans, Austrians, and kapos, but also at women in general and at personal enemies. In this short period after the liberation, Polish women could more freely engage in sexual contact and romantic relations, but they also experienced further victimization by fellow DPs and French, British, and American soldiers. However, their postwar collective experiences do not compare with the violence inflicted upon German and Austrian women by Allied soldiers and liberated foreigners. ${ }^{26}$

In other sections of his novel, Nowakowski focused on the body, bodily liquids, sickness, craziness, and sex. In his masculine perspective, the world seemed to be a gloomy parody of Bakhtin's carnival when the fool becomes the king, the repressed turn into the masters, hunger is transformed into a feast, and misery is replaced by joy. The experience of "the world inside out" in which prisoners and slaves can wear SS uniforms, rape German women, and take German property while drinking and eating gave many of the former prisoners the impression that finally they were the ruling ones. This outburst of hitherto repressed sexuality became the climax of the festival of dissolute freedom that grew like a wave with the advance of the Allied armies. ${ }^{27}$

This eruption of sexuality and violence was more kindly described by Jan Michalski, a DP camp commandant, who quoted a saying circulating in the DP camp: "Fom 
the time of oppressing, a time of embracing." These words evoke a motif that reverberated in many accounts: the will to compensate for the horrible years of war. Michalski remembered the early days in the camp like this: "People were lying at ease in the riverside of Elbe, bathing in the river ... going for farther or closer walks, visiting each other in different camps, going to see friends in Hamburg and Lübeck, and sometimes even further, playing cards . . . but above all, they were making love acrimoniously to overcompensate for the years of forced abstinence." ${ }^{28} \mathrm{New}$ and even improbable sexual relationships flourished seemingly everywhere. Krystyna Vetulani-Belfoure and Maria Horodyska, young women from the intelligentsia who went through forced labor, both wrote in their memoirs about the many relationships that developed in the last weeks of the war or immediately after. ${ }^{29}$ Horodyska mentioned how Polish women working in Krupp factories formed romantic and sexual liaisons with French and Italian POWs. In his autobiographical novel, Nowakowski described a scene of sexual intercourse between a Polish officer and a girl liberated from forced labor. The girl seemed happy to have such an unusual pleasure and wondered if she would be able to content the man as she had never before slept with an officer. After intercourse, the two politely said good-bye and the girl went back to her fiancé. ${ }^{30}$ This story reveals how the illusion of full freedom and a corporeal union of all liberated people was underpinned by prewar patriarchal and classist ways of thinking. Liberation allowed not only for consensual sexual encounters between people of different nationalities but also put people from different social classes into a new proximity with each other.

This sudden corporeal and moral freedom along with the wartime crisis of sexuality turned postwar chaos into a space for female and male sexual fantasies, as well as a space of abuse and sexual assault. The motif of striving for another gender's company appeared in memoirs, short stories, and novels. For some men, liberation created a space for romantic adventure, sexual conquest, and rape, in conversation and imagination, if not in reality. Healthy men embodied power, even if only by wearing a stolen uniform. They could travel at will through a ruined Germany full of vulnerable women in economic difficulties. The perspective of refugee women was completely different. For them, travel through postwar Europe was a dangerous necessity.

The story of Adam Tomaszewski, as described in his semiautobiographical book, is a good illustration of the fantasies common in men's postwar memoirs of this period. The mainspring of his actions and thoughts is "a fatal force" after long sexual abstinence. Driven by a need to compensate for lost years, he traveled to France, Belgium, and through Germany, enjoying the variety of food and female bodies as much as he could. Short affairs allowed him to rediscover femininity with all its attributes, the arcana of love and desire, and his own masculinity. In his narrative, he did not stop at describing the main character's experiences but also referred to the general atmosphere of sexual and romantic tension. ${ }^{31}$

In one scene, the main character (based on Tomaszewski himself) was treated to a tale described as not fit for young ladies in a German tavern full of Polish DPs. The narrator of the story was a "Sergeant B." During the spring and summer of 1945, Sergeant B. and two friends traveled together through Germany, Holland, Belgium, and France in a black Mercedes. Dressed in English uniforms, they bought sexual favors from local women with perfumes, coffee, and silk stockings. Hoping for great fun, 
they went to Hamburg, where someone introduced them to a German policeman. The official humbly agreed to provide them with "first league girls" in the finest surroundings. They ended up drinking champagne in a luxurious house with three ladies who were the "incarnation of the most sophisticated male dreams and desires." Sergeant B. and his friends spent magical moments enjoying the women who were only "for the chosen ones." In the early morning, they had to run and hide on the roof as there was a manhunt for, as one of the girls explained it, "people like you." 32

The story is woven with details such as expensive cars, exclusive prostitutes, shadowy business deals, residences with luxurious furniture, an abundance of alcohol and luxury products, and exceptionally beautiful women with dainty, well-cared for bodies, dressed in elegant underwear. All this creates a male fantasy about power, sex, and adventure. This tale of prestige and dominance seems to show the protagonists' superiority not only over other people but also over their own former selves from a few months earlier: now they are fully men. The use of only an initial, "B.," suggested that what the protagonist did was not supposed to be publicly known later on. In the end, it was only a crazy transgression, an intimate adventure repeated only to other men, even if it never happened. ${ }^{33}$

The image of postwar Europe as a land of romantic and sexual opportunities without traditional restrictions arises from Tomaszewski's writing. He took advantage of an unusual situation that may be interpreted as an attempt to prove his vital life force and assure his masculinity. Referring to the situation of former concentration camp inmates, Margarete Feinstein commented that "many men were traumatized by loss of sex drive, impotence, and their emaciated physiques." 34 The experience of imprisonment, forced labor, and displacement often brought similar consequences. Tomaszewski's case shows not only the pure joy of corporeality but also an experimental polygon on which he tested his masculine skills of seducing women and handling relationships with them, but without any real responsibility, as hardly anything seemed for real at the time. It may have been just a fantasy to compensate for sexual impotence, a diseased body, and undermined sexuality; an expression of overwhelming joy of freedom; or a way of benefiting from the short period of suspended rules. Postwar chaos provided space for all of it.

Not everyone had the possibility or will to travel and explore, or an imagination vivid enough to live such adventures. Additionally, the quickly improvised camps, often overcrowded due to the constant influx of new people, provided a space for romantic and sexual encounters. Many intimate situations happened because of, or in spite of, forced proximity in overcrowded camps. Krystyna Vetulani-Belfoure claimed that when she arrived at a camp in Heilbronn the situation concerning privacy and intimacy was as follows: "a huge empty room spread out in front of our eyes, there was a pile of mattresses in the corner, mostly made of straw . . . There were many people and few mattresses. So it was necessary to share a mattress and sleep by twos ... Some 'cooing couples' were enjoying a common den." ${ }^{35}$ She added that she hoped no one would have "an orgy" in front of everybody's eyes. Kathryn Hulme, a social worker helping Polish DPs at the Wildflecken camp, also mentioned the lack of privacy and described the rooms divided by military blankets into family cubicles in the following way: "You stared at these khaki labyrinths, the last ramparts of privacy to which the 
DPs clung, preferring to shiver with one less blanket on their straw-filled sacks rather than to dress, comb their hair, feed the baby or make a new one with ten to twenty pairs of strangers' eyes watching every move." ${ }^{\prime 36}$

Sexuality in the immediate postwar period was often presented as something animalistic, wild, and sensual. It seemed to not be regulated by any social norms. People focused on primitive corporeal pleasures, almost in its physiological form, without paying particular attention to clothing, flirting, or seduction. The carnivalesque excesses of the liberated people and victorious soldiers trundled along the ruins of the Third Reich. This was the alleged winners' compensation after years of being in camps and prisons, yet they felt their rule was not real and would not last for long.

As time went on, memoirs refer to more "civilized" forms of entering intimate situations. Vetulani-Belfoure mentioned that when she began working for the American administration she was expected to wear makeup. ${ }^{37}$ The requisition of clothes from local Germans allowed DPs to dress better. Women often altered and adapted the clothes they received to look elegant and pretty. People could meet potential partners during dances and parties..$^{38}$ Many Polish DPs, especially young ones, engaged in casual sexual relations and started new relationships. The temporary nature of the place and being far from family and the traditional community reinforced these behaviors. They were free and had a lot of spare time in an environment that lacked the traditional institutions that restrained sexuality and controlled relationships. Thus, many DPs made love and engaged in relationships simply because they could at last. On a collective level, this explosion of sex and indulgence, as well as its further crystallization in fantasies of power and freedom, provided an answer to the feeling of emasculation and disempowerment. Simultaneously, the liberation outburst, like traditional carnivals with their focus on bodily life, fertility, and growth, was a first step of renewal and rebirth of life after the war. ${ }^{39}$ While it had created the potential for regeneration and growth, it also marked the boundaries of emerging norms.

\section{"Out of Concern for the Moral Health of the Society": Relationships, Abortion, and Illegitimate Children}

Many postwar sexual encounters led to short- or long-term relationships. Some of them were very easy to start and very easy to finish. Nowakowski wrote that during the first days of freedom some ex-POWs found "fiancées." ${ }^{40}$ When Krystyna Vetulani-Belfoure confessed to other women in the camp that she was not sure if she wanted to be with her new boyfriend, they said that she should simply move her mattress to another place in the room as a sign that she was finished with him..$^{41}$ Polish DPs engaged in relationships that were highly unlikely in prewar Poland, blurring the boundaries between people of different social backgrounds. The most important criterion for a potential partner remained nationality. Maria Horodyska confessed in her memoir that she and her female friends were persecuted and mocked because of their friendships and relationships with Italian POWs. ${ }^{42}$

Many of the relationships culminated with pregnancy, many with marriage. As an obvious result of the intense sexual life of Polish DPs, there was a baby boom. Histo- 
rian Atina Grossmann noted that the high rate of births among Jewish DPs was seen by the Jewish community as an ideological reminder that mir szeinen doh ("we are here" in Yiddish), reassuring them that they had survived the genocide and the community would live on. ${ }^{43}$ Pregnancy and childbirth brought the reassurance of fertility and male potency and could be interpreted as symbolic revenge, as well as a prefiguration of the imaginary nation of Jews that was to be realized in Palestine. ${ }^{44}$ For Polish DPs as well, bearing children represented a chance to rebuild individual and collective identities. Following a conservative agenda, women learned how to be mothers and men prepared to lead respectable lives as breadwinners providing for their children. Both UNRRA and Polish elites supported this reconstruction of gender norms and encouraged DPs to participate in gender-specific training and activities. ${ }^{45}$ For instance, in the Emmerich camp young Polish girls attended the "Household Management School" to learn cooking, cleaning, sewing, and other domestic tasks. ${ }^{46}$

Although for some people pregnancy and parenthood were a means to find some sense in life, for many it meant only limitations. Commentators indicated a high number of "criminal abortions" and abandoned or murdered children. Krystyna VetulaniBelfoure noted that incidents of abandoned children happened quite often. ${ }^{47} \mathrm{Jan} \mathrm{Mi}$ chalski recalled the case of a Polish DP woman who sold her newborn baby because she could not return home with an illegitimate child, fearing social stigma. He claimed this was not an isolated incident. ${ }^{48}$

Prewar prejudices against "seduced" women and fears of illegitimate pregnancy reverberated in DP camps. While casual relationships were widespread, illegitimate children and their mothers were criticized or even ostracized by the emerging camp community. DP elites framed illegitimate children as a problem for the whole community and a symptom of moral decay, filling reports and camp papers with concerns and warnings. Camp commander Jan Michalski recorded a meeting he had with a very pregnant young woman who was quite determined to get married before she went into labor. The woman claimed that as a man Michalski "does not understand what an unmarried woman with a child, like me, is living through. Everyone points fingers at her and mocks her. Let a child have a regular father and me a regular husband." ${ }^{49}$ As with this young woman, social pressure and the fear of being ostracized pushed women to legitimize their relationships, leading to a large number of marriages among Polish DPs.

In this period, as the first excitation passed, the echoes of prewar norms and morality reverberated. The traditional custodians of morality - priests and teachers-began to come back to their positions. More than nine hundred Polish priests liberated from Dachau and other Nazi camps swiftly covered most of the centers with a Polish population in Germany and Austria with their outposts. ${ }^{50}$ Polish liaison officers from London aimed to provide each camp with a chaplain to arrange spiritual care and meticulously reported pastoral activities. ${ }^{51}$

Prewar morality and the debates surrounding it resurfaced in DP life during the period of normalization. Acceptance of prewar standards was not an obvious choice in the unclear legal and moral situation of this transitory period. For instance, representatives of Polish refugee groups gathered at a congress in Bardowick, Germany, in October 1945. In their report, they claimed that in Polish DP camps existing Polish law 
on abortion must be enforced, that is, termination of pregnancy was allowed only in case of a threat to the woman's life or health or when the pregnancy was the result of a criminal act. Their justification was as follows: "Out of concern for the moral health of the society, the congress condemns sexual misconduct and orders the future commission on cooperation of refugee groups to find adequate remedial measures." 52 The sexual life of Polish DPs was considered far from normative and moral. The representatives of the Polish DPs wanted to put refugees' intimate life in order to rebuild postwar Polishness according to accepted prewar familial, religious, and national values.

Prostitution and female extramarital sex were seen as quintessential examples of moral decay, leading to crime and degeneration. Thus, the DP community, and the nation as a whole, was supposed to be cleansed of unregulated sexuality, especially prostitution, and crime. In the Wildflecken DP camp women accused of being prostitutes were kept in separate blocks, while other camps were entirely cleansed of "criminal and disruptive elements." ${ }^{53}$ In Augustdorf, the Polish gendarmerie rounded up "drunkards, malcontents, [and] agitators" and moved them to a separate penal camp. ${ }^{54}$ Polish liaison officer Artur Friedrich reported to the London government-in-exile that in order to "end banditry" in the Warendorf DP camp, the worst twenty-five "characters" were deported to Walsrode. Soon this action extended to other camps; commandants could send "undesirable or suspicious" people to a camp in Bodenwerder under Polish management and with English guards. The deportees could take their families with them so they would have to take care of them and would not be tempted to escape. The officer concluded in his report that "the experiment was successful." 55

Containing the spread of venereal disease and abortion, a project where goals of UNRRA and Polish elites overlapped, was another means to regulate DPs' sexuality. Camps organized in a military way provided a space open to control and intervention. UNRRA employee Dr. Struther reported that in the Papenburg camp, which housed ten thousand Poles, "there is prevalence of V.D. in both sexes . . possibly due to the proximity of large numbers of Polish troops." He added that abortions were said to be common there, though "they have not, so far, resulted in any fatalities." 56

UNRRA and Polish camp elites combined to institute premarital counseling in the camps as a measure to prevent the spread of venereal disease. ${ }^{57}$ Another UNRRA doctor suggested that "a systematic examination should be made to detect gonorrhea in men and women suspects. If possible, a blood test to find syphilis [should be conducted]." 58 These kinds of measures were opposed by some officials who claimed that compulsory examinations were "unethical and onerous, as it tacitly implies that all female DPs are potential prostitutes," simultaneously pointing out that "the largest reservoir of the disease is in the German population." ${ }^{59}$

Many Polish liaison officers saw German women as a threat of VD contamination as well. They complained about the spread of VD in the Warendorf area and indicated that the source of the problem was German women sneaking into the camps at night. They suggested German women should be kept away from the camps and that DPs should be educated about the consequences of "inappropriate intercourse." ${ }^{60}$ In Brauweiler, Polish authorities decided to build a high fence between the hospital and the camp to prevent the spread of VD. They also attempted to put an end to abortions and investigated the case of a seven-month-old fetus found in a toilet. They searched 
for the mother by conducting medical examinations among the women in the camp. ${ }^{61}$ This example illustrates how the elites used DP camps as a technology of power, facilitating control over refugees' bodies. In another camp, in Heidelberg, an inmate called Wiśniewski was punished by a camp court with three days of arrest after being found at a "woman's place" after curfew. ${ }^{62}$

Schoolchildren and young people were also targeted by the attempts to prevent immorality and its medical and social consequences. In one of the DP camps in Austria teachers expelled two girls from school for attending dancing parties and "flitting between barracks at night." They maintained that this would "protect all students from demoralization." Noting that this radical measure would deprive the girls of "educational and protective influence of the school," they reconsidered the expulsion and decided to give the girls one more week to try to improve their behavior by being watched by the teachers and other students. ${ }^{63}$

The moral panic about promiscuity, prostitution, and crime among Polish DPs was reinforced by concerns about the image of the nation-in-exile in the eyes of the Allies. Editors, officers, priests, teachers, and doctors filled columns of newspapers and bulletins with articles and appeals reminding DPs that they represented Poland and Polishness. Camp commandants, liaison officers, and priests discussed ways to improve the situation and show the best side of the Polish community, defending national dignity. The religious bulletin of the Ingolstadt DP camp reprinted the article "Virtue of Woman," a fragment of a brochure published in 1946 by a refugee publishing house. The author, Eryk Zieliński, condemned "fallen women" who wanted to make their life during the war "easier," forgetting about their honor and about the fact that they were Poles. He complained that the promiscuity of these "perky little women" in the aftermath of war ruined the reputation not only of Polish women but of Poland itself. He insisted that "everything must be done to remove this stigma of war." The camp's priest added under the article, "Our duty is to save what has not died yet, to give a brotherly hand to those fallen and to help them to rise." 64

Debates about acceptable relationships and illegitimate children followed the uncontrolled eruption of sexuality after the end of the war, marking the beginning of normalization. The time of the carnival transgressions slowly ended with the emergence of new powers over the bodies and sexuality of displaced Poles, now gathered in an easily regulated camp space. However, this process did not simply mirror traditional morality but absorbed different elements, traveling toward a new morality.

\section{Reforming the "Topsy-turvy World": Marriages, Families, and "Fallen Women"}

A social worker from the Hanau camp recalled that one Saturday forty-five Polish DP women dressed in white bridal gowns came to the church to get married. In less than three hours the ceremony was over, to the satisfaction of those for whom these were emergency marriages. ${ }^{65}$ While Germans dealt with "the marital crisis" and "the sexual crisis," Poles attempted to restore the model of marital domesticity within the undomestic space of a refugee camp. ${ }^{66}$ The wider context of the DP camps' debates on sexuality was the process of rebuilding the Polish nation after the hecatomb of 
war. Properly regulated sexuality, especially female sexuality, formed the core of what camp elites and liaison officers referred to as the collective moral health.

Jan Michalski dedicated a full chapter of his memoir to the story of the "Legitimate Child," illustrating problems, procedures, and people's attitudes related to marriage. He observed that there were many couples in the camp that should get married: "young people who love each other." 67 Acting as the camp commandant, Michalski instituted procedures to legalize camp marriages according to both Polish and German requirements. First, two weeks before the marriage an announcement would appear on the camp blackboard asserting that the groom and the bride were single. Second, the bride and groom needed to present witnesses (with reliable identity documents) who could testify that they were not already married. Third, a person was chosen as an intermediary with the German Municipal Office, which needed to register all marriages conducted on German soil. Lastly, Michalski prepared special instructions for the ceremony, including that "the groom and bride along with the witnesses should come to the wedding sober and in neat clothes." 68

Michalski presided over a wedding from behind his desk, which was covered with red fabric (possibly a former Nazi flag) and decorated with a big crucifix and two candles. Afterward the bride and the groom ran to the town to get married in the Municipal Office, which was possible only after providing a document with a stamp. ${ }^{69}$ Legitimizing sexual relationships in DP camps brought normalization on the wave of rising conservatism. The possibility of marriage put an end to relationships not recognized as socially and culturally normative. It meant a return to tradition, but also guaranteed a safer place in the social fabric for those who feared being ostracized for their sexual transgressions.

DPs, especially men, interpreted changing romantic and sexual norms as a symptom of garbled values and disrupted order. The author of the bitterly humorous poem "Topsy-turvy World," published in the camp bulletin in Schwäbisch Hall, complained about the new trend according to which people avoid their own kind and "a Polish woman is always happy to go out with an American," "a Lithuanian is in love with a Ukrainian," "a Romanian wants to be a fiancé of an Italian." To add to the confusion of values "a Jew reads the Bible in the Calvinist church." The conclusion of the poem was that the world was at its least stupid in a bottle of vodka. ${ }^{70}$ People's anxieties toward the new transitory realities of DP camps, perceived as confusing and unstable, converged in the critique of sexual and romantic issues, which were seen as a force disrupting the national order of things.

Polish DPs saw reforming and normalizing sexuality as a passage from war to peace that was supposed to cleanse and strengthen the biological substance of the nation. Reports, DP papers, and the exile press were filled with alarming articles on "promiscuity," "demoralization," "moral decay," and "degeneracy." One DP, Eryk Zieliński, published a short moralistic novel, World of Janeczka: A Refugee Story, in Hamburg in 1946. The main protagonist, a simple girl deported for forced labor when she was fifteen years old, prepares for her wedding, having gained the respect and love of her fiancé, who changed from a womanizer into a faithful partner. Even though they had been in a relationship for three years she did not have a child ("How could she? Without the wedding? Without the blessing?") and her fiancé had not dared to 
"befoul her." Janeczka, who clearly stands out from other girls in the DP camp because of her chastity and mild personality, marries Franek and happily shares all the hardship of life with him. They receive a crummy but private room that Janeczka turns into a "folksy" space with "colorful kerchief on the wall," flowers, and "little curtains." Together they create an exemplary household, while other DPs live among "rows, noises, and cries," and when their son is born they decide to return to "their Polish land" where "golden apples weigh the branches toward the ground."71

Polish camp authorities tried to assist the reconstruction of "normal families" by logistical arrangements, regulations, and attempts to get better accommodations for couples. Discussions about better and separate lodging for families reflected the wish to rebuild a "proper" society and end demoralization. Representatives of the Polish Union proposed that any married couple receive privileges such as a separate flat in order to encourage people to legitimize their relationships and refrain from promiscuity. ${ }^{72}$

To combat "wild marriages" (couples who cohabitated without a formal marriage ceremony), priests, cooperating with Polish camp councils, used persuasion, incentives, and repression. In one atypical case, they managed to get the support of a British military official who allegedly helped to prepare an appeal, reprinted in the DP bulletin: "Poles! Be faithful to your sacred Catholic faith! Do not follow paths of paganism. Don't let your children grow up in shame and disgrace. Illegal marriages will cause vexation and misfortune for your entire life. You are Catholics and you know what to do-get married in church!"73 The author claimed that unmarried couples would be separated and placed in different parts of the British zone. In their reports, priests described their fierce fight with the "plague of wild marriages." Reverend Dąbrowski declared that in a camp in Adelheide he managed to liquidate 75 percent of them before February 1946. In the Heilbronn DP camp, no family could receive a flat without a written confirmation from the priest that they were officially married. ${ }^{74}$

The fight against "wild marriages" continued as long as the DP camps existed. Reverend Edward Lubowiecki, from the diocese for Poles in Germany, enumerated the "sins" of Polish DPs. One of the most important was a problem of "dissolute life," which caused the spread of venereal disease, especially among the youth. ${ }^{75} \mathrm{He}$ demonstrated particular concern for the situation of young girls who worked for the Americans. He believed they were deeply endangered and possibly already "corrupted." In his estimation, young girls could not resist the temptation to marry foreigners nor to refuse small gifts that stimulated their vanity and led to an immoral life. Lubowiecki's beliefs were part of a more widespread phenomenon, as Dagmar Herzog has noted: "Because the postwar era often saw new occupation soldiers vying for the attention of local women, nationalist and masculinist resentment against these interlopers was yet another factor reinforcing trends toward more conservative sexual mores, and especially toward renewed restrictions on women's sexual freedoms."76 Camp elites condemned mixed marriages (between Poles and non-Poles) as "loss of blood," seeing them as an obstacle to the reconstruction of the Polish family. ${ }^{77}$ Priests opposed them fiercely and refused to give the sacrament to Poles who wished to marry foreigners, while condemning German priests who agreed to do so. They meticulously compiled statistics, indicating, for example, that in 1947 in the American zone of Germany there 
were 1,009 marriages between Poles, 86 between Poles and Ukrainians, 49 between Poles and Germans, and 38 between Poles and people of other nationalities. ${ }^{78}$ Camp leaders and journalists often described such marriages as invalid, illegal, and against the national honor. As a result, people in mixed marriages, especially those in relationships with Germans, tended to be discriminated against and ostracized, even after they had left the DP camps. Jan Dubiel, a Pole who emigrated to Chicago, begged the secretary of the American Committee for the Resettlement of Polish Displaced Persons for help, complaining that a neighbor had invaded his home with an axe, calling him and his family "DP, Nazi, Gestapo." He was told that nothing could be done because his wife was German. ${ }^{79}$

For many women, who were often discriminated against in resettlement schemes, marriage with a foreigner served as a ticket to a better life. It could help them to resettle in another country or gain money and benefits. Some Polish women wanted to marry foreigners to be able to emigrate and actively sought such options. Propositions of marriage from Canadians and Americans seemed especially lucrative, even if some of these men were evidently trying to take advantage of the DP women. In some cases, such deals ended in disappointment. Krystyna Vetulani-Belfoure wrote in her memoir that an Estonian girl working in the office warned them to not get engaged with foreign boys like Americans or Canadians too fast, "because they look cute in the uniforms but when they take uniform off and put overalls on they demand breakfast at five in the morning." ${ }^{80}$ But Krystyna still concluded that "marrying an American (or an Englishman or a Frenchman) creates an opportunity to leave Europe faster." 81

The ceremony of marriage itself played an important role in rebuilding national and cultural identity. Michalski, writing his memoir from the perspective of anti-religious communist Poland, noticed how important symbols were for marrying couples and the whole camp community. "Some brides," he wrote, "why should we hide it, were expecting to become mothers soon, so they preferred not to wait with the marriage ... It was common that a bride in an appropriate wedding dress and obviously with a wreath on her head led a child by hand to the altar and held another one, a newborn, in her arms . . . She was marrying their father after all. Besides that, why children should not be present on their parents' wedding?" 82 Ideally, the marriage ceremony was done according to religious rites. Local Catholic churches, especially in Catholic regions of Germany and Austria, witnessed many DP marriages given by the local priests.

The revival of religious values inhibited sexual freedom. Religion was a significant factor in restraining sexuality, restoring traditional gender roles, and promoting the importance of the family. As soon as the DP camps crystallized, priests undertook pastoral activities. They actively opposed extramarital sexual relationships, considering them a sign of moral havoc. For instance, one of the Polish chaplains in a DP camp complained, "In spite of the Polish chaplains' work the moral state in the Polish camps is not satisfactory. Especially there are very many illegal marriages." ${ }^{83}$ This interest in private life, including intimate relations, and a will to control and regulate may be interpreted as a part of the wider project of constructing an ideal Catholic patriotic family led by the idealized "Mother Pole." 
In the following years, those who voluntarily or involuntarily persisted in what priests considered undesirable behaviors were labeled criminals, prostitutes, and outsiders, or morally lost, derailed, and brutalized victims of war who needed to be reformed. Poles who served sentences in Allied-controlled prisons were depicted either as habitual criminals and degenerates or as victims of war and Nazi brutality. Similarly, the image of women who did not comply with conservative sexual standards oscillated between selfish sinners and naïve victims of war and the "topsy-turvy world" who had to be reformed. ${ }^{84}$

The presence of a high number of unmarried single mothers was a contentious issue both for UNRRA and for the Polish community. Dr. Struther, having visited Polish DP camps in the British zone, mentioned "an outstanding problem . . . of unmarried mothers and unwanted babies, for both of whom a home is regarded as necessary by the nursing staff." ${ }^{85}$ On one hand, they faced discrimination and exclusion. On the other, some priests and social activists undertook paternalistic efforts to reeducate them, a rhetoric that echoed early twentieth-century approaches to the issue of "fallen women." 86 They were seen as in between, still possible to incorporate in the national body, especially if they had children, "a national treasure," under their care. ${ }^{87}$ The nation, weakened after the wartime bloodshed and now undergoing the spiritual and biological reconstruction, needed them.

"Save unaccompanied Polish maidens, Polish women and their children from the horrible fate-disregard in the hostile land and communist poison!" exhorted Reverend Franciszek Filarek, a priest in the center for single women with children in Mariental, in his letter to Charles Rozmarek, the head of the Polish American Congress. It was already 1949 and the 220 women and their children gathered together and put under the control of the priest represented the remainder of the postwar "immorality" that had not been straightened up by marriage, adoption, or other means. Filarek explained that many of the women had been deported from Poland as schoolchildren and grew up "among cruel conditions." After the liberation, men "exploited their inexperience with the promises of marriage and brought them to fall." However, many of these "sinful" relations ended up with marriage, while some remained "fallen" and "ill-used." These "fallen women" focused all their energy on the upbringing of their children, so that they could "stay up morally." According to the priest, they deserved help because they did not cease to be "our beloved Polish souls" and because almost all the children "come from Polish men." He noted that they were ill-treated by resettlement officials and communist liaison officers who deprived them of DP cards and tried to force them to return to Poland. The women reportedly maintained that they would "keep their children and if there will be nothing to feed them with rather kill them than give them to communists." 88

These arguments were supposed to convince Rozmarek to facilitate their emigration to the United States, but his answer was straightforward: "There is no need for this kind of persons among Polish Americans." ${ }^{89}$ In the rhetoric Filarek employed, women were presented as innocent and passive victims with limited agency. It mirrored early twentieth-century Polish reformers' approaches to prostitution, seen as violent coercion, and to prostitutes, who had to be rescued from their plight through charity. ${ }^{90}$ Punishment for the orgy of freedom - in the form of social condemnation, 
separation, exclusion from the community and from the emigration schemes, and material deprivation - was directed at women and their illegitimate children, a burdensome remainder of the "immorality" that corrupted the Polish national body.

On a more general level, normalization in the refugee community meant the shift from the illusionary empowerment of DPs to old hierarchies. Borowski expressed his disillusionment at this shift in an untitled poem. It begins "Slaves, wretched and hungry / Arose to push the sphere of the world," but by the end of the poem, everything was "As before: a portion of soup / Who was a prisoner is a prisoner / And an SS man goes free." ${ }^{\prime 11}$ Kazimierz Winnicki, a convict in an Allied prison, expressed this sense of being betrayed and deprived of freedom and compensation in a letter to the priest Ćwiklik: "My body suffers, my soul suffers, huge sorrow embraced me. Through the mountains, forests, fields I am sending you my pain. Formerly barbed wire, today bars. Formerly the enemy, and today who?"${ }^{\prime 92}$

Many Poles believed they found themselves in a grotesque copy of Nazi Europe, with camps, barbed wire, barracks, and insufficient food. Their frustration, envy, and rage grew with the conviction that Germans lived better than DPs and that they avoided punishment. Anti-Germanism, underpinned by anti-Prussian attitudes that originated from the time of the partitions, was widespread. DPs widely believed that Germans had found a way to regain their privileged position while the Poles remained subordinate, against everything the Allies had promised and against moral justice. Fraternization was seen as proof that German and Allied soldiers now ruled the country. The editors of Jutro pracy (Working tomorrow) printed a racist drawing entitled "The German Family Yesterday and Today." In one panel, the drawing showed a couple and a child in Nazi uniforms, and in a second panel the same woman was pictured with a black American soldier and a "squared [biracial] child." 93 The feeling of being fooled grew along with disappointment over the position of DPs in the postwar world, especially their relationship to local Germans and Austrians. The hopes of the first postwar days turned out to be just illusions, abundance just an excess, and freedom just a short episode.

\section{Conclusion}

Debates on sexuality in the DP community focalized the wider problems Poles faced: feelings of emasculation, coping with war trauma, and the challenges of rebuilding a community in exile. The dynamics of sexuality of Polish DPs can be characterized by a carnivalesque structure of oppression, eruption, and normalization. The eruption of sexuality and other bodily experiences at the moment of liberation was an illusion of perfect freedom in which Poles indulged to compensate for their years of oppression. Multiple intimate encounters seemed to be relatively free from social and class norms, while in fact constituting a chaotic mix of new and old, allowed and forbidden, "moral" and "immoral." This gloomy festival of sexuality and corporeality enabled forbidden actions, including promiscuous sex, eating, drinking, and rape.

Many liberated people seemed to believe that they would now be the privileged ones. They received food and cigarettes, German houses and clothes (including SS 
uniforms), German bodies to rape and beat, and finally the position of victims who should be assisted in all possible ways and granted unlimited freedom. It seemed like wartime power relations had been upturned, and for a short while the slaves became the rulers and the masters became slaves. The joy of entering this new reality along with the trauma of years of oppression exploded in an uncontrollable orgy of freedom with its climax in sex liberated from social norms.

This enthusiasm began to melt away as soon as they realized that their liberators were in fact new decision makers who had power to classify them as "DPs." After a longer stay in the DP camps, the carnival spirit slowly came to an end, bringing disappointment and a will to clear things up. Sexuality, repressed during the war, flourished in the DP camps in the initial stage of their existence, but as the camp community grew, the sexual life of its inhabitants began to be regulated. The absolute freedom of the first period after the liberation gave way to attempts to restore traditional cultural norms by promoting marriage, reuniting families, and ending socially inconvenient relationships.

The legitimization of intimate relationships took place in an atmosphere of insecurity, transience, and chaos. While in the DP camps more was allowed, accepted, and forgiven than in traditional Polish communities, under pressure from priests, teachers, doctors, and other members of the elite the orgy of freedom was followed by a high number of marriages. Some DP communities were judgmental and restrictive; they used ostracism and psychological violence to regulate the intimate life of their inhabitants. Marriage itself was double-edged. It could give women a better social position, an opportunity for a better life through emigration, or an improved economic position. In some cases, however, it became a source of social and personal oppression.

The normalization in Polish DP camps, which came after the initial excitement and chaos, was not a copy of Polish prewar cultural norms but a new hybrid form containing traces of wartime trauma, transgressive postwar actions, and provisional arrangements from below and from above in the reality of the Allied occupation. National and religious revival started in the DP camps as leaders aimed to save Poles from total moral and corporeal "degeneration." For many DPs, it meant that out of the postwar chaos a new order emerged in which they were not the agents but the pawns. Thus, the short carnival of freedom ended and they were now subjected to renewed social norms. The new order began with putting their sexual and intimate lives in order to avoid being excluded or marginalized. Those who persisted in behaviors considered undesirable and who tried to evade the disciplining power of elites and UNRRA were labeled either as criminals, prostitutes, and outsiders or as brutalized victims of war.

This was a part of a wider project of reconstructing the Polish family and the Polish nation after wartime losses and moral decline. Fears of a degenerate nation concentrated around the female body. Women were depicted as either victims of recklessness and fraternization or as culprits who brought shame to the entire nation. To reform their sexuality and mores meant to include them in the body of the nation, undergoing spiritual and biological reconstruction. The carnival of freedom with its excess, indulgence, and jumbled values was a first step in the postwar revival and regeneration of the individual and of the nation, carrying potential for a return to life. 


\section{$\diamond$ About the Author}

Katarzyna Nowak, PhD, is a research associate on the project "Reckoning with Refugeedom: Refugee Voices in Modern World History" funded by the Arts and Humanities Research Council. She completed her PhD on the experiences of Polish Displaced Persons at the University of Manchester, UK.

E-mail: Katarzyna.nowak@manchester.ac.uk

\section{$\diamond$ Notes}

1. Adam Tomaszewski, Chleba naszego powszedniego [Our daily bread] (Toronto: PFW, 1988), 151. All translations by the author unless otherwise noted.

2. The situation in the Soviet zone exceeds the scope of this article. Anna Jaroszyńska Kirchmann, The Exile Mission: The Polish Political Diaspora and Polish Americans 1939-1956 (Athens: Ohio University Press, 2004), 60.

3. Malcolm Proudfoot, European Refugees: 1939-52. A Study in Forced Population Movement (London: Faber, 1957), 115.

4. George Woodbridge, ed., U.N.R.R.A.: The History of the United Nations Relief and Rehabilitation Administration (Vols. I-III) (New York: Columbia University Press, 1950), 502.

5. Anna Holian, Between National Socialism and Soviet Communism: Displaced Persons in Postwar Germany (Ann Arbor: University of Michigan Press, 2011), 57.

6. Mikhail Bakhtin, Rebelais and His World (Bloomington: Indiana University Press, 1984), 235, 246, 255, 333-339; Peter Stallybrass and Allon White, The Politics and Poetics of Transgression (Ithaca, NY: Cornell University Press, 1995), 6-14, 183-187.

7. Annette Wieviorka, The Era of the Witness (Ithaca, NY: Cornell University Press, 1998), 132.

8. Tadeusz Drewnowski, ed., Postal Indiscretions: The Correspondence of Tadeusz Borowski, trans. Alicia Nitecki (Evanston, IL: Northwestern University Press, 2007).

9. Tadeusz Borowski, Poezje [Poems] (Warsaw: Państwowy Instytut Wydawniczy, 1972), 115.

10. Ibid., 129-137.

11. Ibid.

12. Ibid., 119.

13. Jan Rydel, "Polska okupacja" w pótnocno-zachodnich Niemczech 1945-1948: Nieznany rozdział stosunków polsko-niemieckich ["The Polish occupation" in northwest Germany in 1945-1948: An unknown part of Polish-German relations] (Kraków: Księgarnia Akademicka, 2000), 186-195.

14. Kazimierz Kosicki, Duszpasterstwo wsród Polaków w Niemczech w latach 1945-1950 [Pastoral ministry among Poles in Germany, 1945-1950] (Lublin: Wspólnota Polska, 1993), 192.

15. Jarosław Pałka, Machteld Venken, and Krzysztof Zalewski, eds., Żotnierze generała Maczka: Doświadczenie i pamięć wojny [General Maczek's soldiers: Experience and memory of war] (Gdańsk: Replika, 2013), 241.

16. Kazimierz Koźniewski, ed., Pamiętniki emigrantów, 1878-1958 [Emigrants' memoirs, 1878-1958] (Warsaw: Czytelnik, 1960), 128.

17. Stanisław Nowakowski, ed., Muzułman wraca do domu i inne pamiętniki więźniów hitlerowskich obozów koncentracyjnych [Muzulman returns home and other memoirs of concentration camp prisoners] (Kraków: KAW, 1985), 300.

18. Borowski, "Koniec wojny" [The end of the war], in Poezje, 107.

19. Tomaszewski, Chleba naszego powszedniego, 151. 
20. Ibid.

21. Ibid.

22. Ibid., 151-155.

23. Krystyna Kersten and Tomasz Szarota, eds., Wieś polska 1939-1948: Materiały konkursowe [The Polish village, 1939-1948] (Warsaw: PWN, 1967), 412-413.

24. Tadeusz Nowakowski, Camp of All Saints, trans. Norbert Guterman (New York: St. Martin's, 1957), 144.

25. Ibid., 144-145.

26. Miriam Gebhardt, Crimes Unspoken: The Rape of German Women at the End of the Second World War (Cambridge: Polity Press, 2016); Robert Lilly, Taken by Force: Rape and American GIs in Europe During World War II (Basingstoke, UK: Palgrave Macmillan, 2007).

27. Bakhtin, Rebelais and His World, 81-82, 410.

28. Jan Michalski, Obóz przy Sandstrasse [The camp at Sandstrasse] (Warsaw: Czytelnik, 1975), 258.

29. Vetulani-Belfoure's memoir was published in already independent Poland while she lived in the United States. Horodyska's book came out in 1989, just before the change of the system. Krystyna Ewa Vetulani-Belfoure, Z ziemi egipskiej, z domu niewoli . . w wspomnienia [From the Egyptian land, from the house of slavery ... memories], ed. Maria Rydlowa (Kraków: Czuwajmy, 1997); Maria Horodyska, Doczekać świtu [To live to see the dawn] (Warsaw: Czytelnik, 1989).

30. Nowakowski, Camp of All Saints, 63-64.

31. Tomaszewski, Chleba naszego powszedniego, 216.

32. Ibid., 216-217.

33. Ibid.

34. Margarete Feinstein, "Jewish DPs and Questions of Gender" (Göttingen: ITS Year Book, 2014), 160.

35. Vetulani-Belfoure, Z ziemi egipskiej, 37.

36. Kathryn Hulme, The Wild Place (Boston: Little, Brown, 1953), 90-91.

37. Vetulani-Belfoure, $Z$ ziemi egipskiej, 57.

38. Horodyska, Doczekać świtu, 176-178.

39. Renfrew, Mikhail Bakhtin, 141-143.

40. Nowakowski, Camp of All Saints, 276.

41. Vetulani-Belfoure, $Z$ ziemi egipskiej, 39.

42. Horodyska, Doczekać świtu, 168.

43. Atina Grossmann, "Victims, Villains and Survivors: Gendered Perceptions and SelfPerceptions of Jewish Displaced Persons in Occupied Postwar Germany," Journal of the History of Sexuality 11, nos. 1-2 (2002), 291-318:304.

44. Ibid., 305-315.

45. On rehabilitation according to gender and familial norms, see Tara Zahra, "The Psychological Marshall Plan': Displacement, Gender, and Human Rights after World War II," Central European History 44 (2011): 37-62.

46. Adam Janta-Połczyński, Raport sytuacyjny, 25.5-25.6.1946, A.XII.47/78E p.II, Polish Institute and Sikorski Museum, London (hereafter PISM).

47. Vetulani-Belfoure, Z ziemi egipskiej, 141-142.

48. Michalski, Obóz przy Sandstrasse, 391-392.

49. Ibid., 167.

50. Kosicki, Duszpasterstwo, 86.

51. A.XII.54/5, PISM.

52. Protokół zjazdu przedstawicieli środowisk polskich na terenie okupacji brytyjskiej w Niemczech, A.XII.47/89, PISM. 
53. Interview with Stefan Czyżewski (transcript), 14.09.1998, RG-50.549.02*0023, p. 62, United States Holocaust Memorial Museum.

54. A.XII.47/78E/partII, PISM.

55. Artur Friedrich, Sprawozdanie z działalności, 1946, XII.47/78F, PISM.

56. Dr. Struther, UNRRA Report on Field Survey of Health of D.P. Children, p. 8, S-0409 0022-0005, UNRRA Collection in the United Nations Archives, New York (hereafter UN).

57. Ibid., 5.

58. Dr. Baras, Health Policy, 29.07.1945, p. 2, S-0414-0001-0013, UN.

59. A. Sainz de la Pena, Examination of DPs for Venereal Disease, 7.11.1946, S-0414-00030012, UN.

60. K. Szagon, Sprawozdanie za czerwiec 1946, 5.07.1946, A.XII.47/78F, PISM.

61. Sprawozdanie. Polski obóz 'Warta' Brauweiler, 05.1946, AXII47/78E/p.II, PISM.

62. Wykaz przestępczości, A.XII.47-78E/p.II, PISM.

63. Protokół nr 3. Odpis, f.380/024, Piłsudski Institute of America, New York (hereafter PIA).

64. Eryk Zieliński, “Cześć Kobiety,” Świt Wolności [Dawn of freedom], 23.03.1947, p. 3, f.592/155, PIA.

65. Silvia Salvatici, "Lost Homelands Lost Homelands and Reconstructed Homes: Gender and Displacement in Post-war Europe," in Landscape After Battle, ed. Suzanne Bardgett, Davide Cesarani, Jessica Reinisch, and Johannes-Dieter Steinert (London: Vallentine Mitchell Publishers, 2010), 149-162: 151-152.

66. See Dagmar Herzog, Sex after Fascism: Memory and Morality in Twentieth Century Germany (Princeton, NJ: Princeton University Press, 2005), 65-67.

67. Michalski, Obóz przy Sandstrasse, 156.

68. Ibid., 156-157.

69. Ibid., 158-161.

70. "Przekręcony świat," Nasze życie [Our life], 9.06.1946, p. 19, S-0436-0045-0001, UN.

71. Eryk Zieliński, Świat Janeczki: Opowieść wychodźcza [The world of Janeczka: A refugee story] (Hamburg: Książnica Domu Polskiego, 1946), 47.

72. Protokół zjazdu przedstawicieli środowisk polskich, 312/PSDP/519/89, PISM.

73. Na szlaku [On the trail], 15.05.1948, p. 7, f.823/155, PIA.

74. Kosicki, Duszpasterstwo, 154.

75. Odpis. Stan moralny ludności polskiej w Niemczech, 312/PSDP/519/49, PISM.

76. Herzog, Sexuality in Europe, 98.

77. “The Dangers of Mixed Marriages,” Nowy Świat [New world], 16.04.1948, 4.

78. Kosicki, Duszpasterstwo, 155-156.

79. Correspondence between Jan Dubiel and Edward Plusdrak, 17-29.11.1949, 30/234, Immigration History Research Center, Minneapolis (hereafter IHRC).

80. Vetulani-Belfoure, $Z$ ziemi egipskiej, 78.

81. Ibid., 78.

82. Ibid., 165.

83. Polish Chief Chaplain R.-C. British Zone, Memo, 10.11.1947, FO1052/176, the National Archives, London.

84. Correspondence between Franciszek Filarek and Charles Rozmarek, 30/234, IHRC. Military Government Court Records, RG466/1142598, NARA.

85. Dr. Struther, UNRRA Report on Field Survey of Health of D.P. Children, 26.11.1945, p. 2, S-0409-0022-0005, UN.

86. Keely Stauter-Halsted, The Devil's Chain: Prostitution and Social Control in Partitioned Poland (Ithaca, NY: Cornell University Press, 2015), 237. 
87. “Children's Health," Biuletyn Informacyjny, Maczków, 25.8.1947, 462/024, PIA.

88. Franciszek Filarek's letter to Charles Rozmarek, 17.09.1949, 30/234, IHRC.

89. Ibid.

90. Stauter-Halsted, The Devil's Chain, 118-120.

91. Borowski, Poezje, 158.

92. Letter of Kazimierz Winnicki, 6.02.1949, f.249/024, PIA.

93. Jutro Pracy [Working tomorrow], 28.07.1946, p. 6, f.464/024, PIA. 